\title{
Re-examining "Redesign” in Critical Literacy Lessons with Grade 6 Students
}

\author{
Jessica Mantei $^{1} \&$ Lisa Kervin ${ }^{1}$ \\ ${ }^{1}$ University of Wollongong, NSW Australia \\ Correspondence: Jessica Mantei, University of Wollongong, NSW Australia. E-mail: jessicam@uow.edu.au
}

Received: August 22, 2016

Accepted: September 8, 2016

Online Published: September 10, 2016

doi:10.5430/elr.v5n3p83

URL: http://dx.doi.org/10.5430/elr.v5n3p83

\begin{abstract}
In children's literary texts, ideologies aligning readers with discourses of certain communities often remain uncontested, potentially privileging those views and values over others. Critical literacy, therefore, is important so children can contest positions taken in literary texts and consider how their own texts in turn position others. This inquiry examined redesign as a pedagogical approach for developing critical literacy with 12 year old students as they deconstructed messages they identified in a short film and then reconstructed alternative viewpoints with new digital literary texts (redesigns). Findings revealed that the redesign cycle supported learners as they moved through a process of interpreting the text, critiquing ideologies they perceived and then working to imagine new perspectives and alternate viewpoints in their own literary text creations. This paper explores the implications for supporting learners with different critical literacy skills to develop those skills and express their understandings through the creation of digital literary texts.
\end{abstract}

Keywords: Critical literacy, Literacy pedagogy, Primary school, Literacy learning, Children's literary texts, Digital writing

\section{Introduction}

One purpose of schooling is to support students' development for meaningful participation in and contribution to their present and future communities. Exactly what this involves continues to change in the face of increasingly diverse populations and new technologies that allow broadened interactions with people and texts and, as such, demand new literate practices (Comber, 2011; Cope \& Kalantzis, 2009).

Within schools, literary forms such as picturebooks and short film convey participatory messages about belonging to a community (Short, 2009) and it is well documented that they position readers to align themselves with their taken-for-granted ideologies (Kress \& van Leeuwen, 2001; Luke, 2000; Serafini, 2012; Short, 2009). This is broadly achieved through the silencing of marginalised groups and the inclusion of dominant voices and perspectives (Haynes \& Murris, 2012; Janks, 2010). Readers with a critical eye can perceive and make choices about issues of participation and exclusion (Leland \& Harste, 2002) in literary texts. Thus empowered, readers may align themselves with the ideologies presented; reject them in favour of alternative ones or perhaps refrain from taking a position at all. The power lies as much in the ability and opportunity to make choices as in the decisions themselves.

This paper examines the responses of one group of students (aged 12 years) in an Australia elementary school to messages they perceived in a short film, identified here as literary text. The paper draws on a larger project underpinned by critical literacy theory examining how Janks' redesign cycle (2010) may be used to support learners to critique literary text; to deconstruct perceived messages; and to create new literary texts that imagine alternative perspectives or possibilities for those messages. The students responded to a digital literary text, Ruhemann and Tan's (2010) short film The Lost Thing (http://www.thelostthing.com), then created their own 2-3 minute digital multimodal literary texts with the aim of conveying alternative perspectives of the messages they had perceived.

A "literary text" in our research is defined as a text recognised for its personal, social, cultural and aesthetic elements that convey something of the ideologies, values and beliefs of the culture within which it is created (Kalantzis \& Cope, 2012). Literary texts (and by extension digital literary texts) employ literary, audio and visual devices that invite literal, figurative, critical and creative interpretations and responses from the reader (Holliday, 2008; Kalantzis \& Cope, 2012). In contrast, non-literary texts tell more straightforward stories that may present morals rather than exploring complex universal life themes such as freedom or belonging. 


\subsection{Students as Critical Consumers and Creators of Literary Text}

Arizpe, Farrell and McAdam (2013) identified stories (such as literary texts), and their sharing as a fundamentally human experience presenting opportunities for understanding oneself and others. Making meaning from these stories is considered a transaction between the unique personal history, experiences, knowledge of the world, and practices of the reader (or listener) and the text (Rosenblatt, 1982; Vasquez, 2010). From birth, stories support identity construction through messages about who to be, what to do and how to "fit" within a community (Arizpe, et al., 2013; Short, 2009).

Of course, the ways children experience story changes as they move from the familiar practices of home and family to the practices and texts of school, peers and popular culture more broadly (Genishi \& Dyson, 2009). Children may experience within these broader communities new modes of expressing meaning, new ideologies and perspectives on taken-for-granted views of their own groups, potentially broadening their world views, and developing better understandings of and relationships with others (Arizpe, et al., 2013; Short, 2009). However, Genishi and Dyson (2009) observed that the texts and, more specifically, stories promoted by schools located in communities where the dominant language is English tend to be embedded in "a dominant Western literacy tradition" (p. 75), potentially excluding the home and community practices of students from backgrounds other than English. This presents a challenge for educators to rethink their own taken-for-granted views about what constitutes "literature", how they themselves are positioned by these texts and how they are used.

Literary texts use expressive language, images, sound and movement to build complex narratives that offer multiple perspectives and afford diverse interpretations of meaning (Gibson \& Ewing, 2011). Such texts represent opportunities for critical literacy. In the Australian context, critical literacy theory and pedagogy is grounded in Luke and Freebody's (1999) foundational work that articulated four separate, yet interrelated social practices for being a consumer and a creator of text. Underpinning their "four resources" model for literacy practices is the view that texts always relate to issues of politics and power (Luke, 2000). And as such, the reader is required to critique the ideologies conveyed within a text in an effort to transform dominant views and account for more diverse perspectives (Luke, 2000; 2012). In classrooms, students of critical literacy move beyond reading and thinking critically to consider social inequities conveyed within texts and to challenge the status quo with new texts that express personal identities and actions in the world (Comber, Thompson \& Wells, 2001; Dallacqua, Kersten, \& Rhoades, 2015; The New London Group, 1996).

The practice of critical literacy education with a focus on literary texts has been taken up in classrooms in a range of ways. Through examinations of literary texts, students have developed their "personal cultural identities" (Short, 2009, p. 3) and explored their multiple identity positions within the different groups to which they belong (Janks, Dixon, Ferreira, Granville, \& Newfield, 2014). They have examined the ways their identities, such as gender, culture, or age, are represented in the texts on offer in schools (Foss \& Carpenter, 2002; Vasquez, 2010) and the community more broadly (Short, 2009), and they have expressed their own perceptions of place within a community with the creation and sharing of new literary works (Janks \& Comber, 2006; Mantei \& Kervin, 2014). Common among these projects is a critical literacy focus on the deconstruction and subsequent creation of new texts that imagine new possibilities and alternative perspectives of self and others that promote greater understandings between groups (Janks, 2010; Leland \& Harste, 2002; Vasquez, 2010).

Key to this view of critical literacy is the transformation that occurs in the promotion of social action through the creation of new texts. Luke (2000) argues that social action is more than critique and more than writing for reflection. Comber and colleagues (2001) concur, defining social action as the development of a sense of "what might be possible" (p. 453) in a climate where learners can accrue sufficient social capital to understand their ability to alter their own and others' personal life trajectories. This view of social action is supported in Luke's (2012) observation that the taking of social action, while it may be a physical act, can also be the repositioning of oneself in relation to prevailing discourse. That is, social action can be as simple as "making a difference to the way we think" (Janks, et al., 2014, p. 12) by sharing new views or alternate ideologies through the careful design and subsequent creation of new texts.

To consider the design of a text is to examine the elements from which it was constructed, that is, the ways the linguistic, audio, visual, gestural and spatial modes combine for the multimodal creation of meaning (Kress \& van Leeuwen, 2001; The New London Group, 1996). An examination of the ways these modes work together supports the development of understanding about the representational and social functions, the structural and intertextual functions, and the ideological function, which in turn allows the reader to identify voices shared and silenced (Cope \& Kalantzis, 2009). Knowledge about the design and potential for a text's redesign offers the reader a unique opportunity for the transformation of meaning and new representations of identity in new texts (Cope \& Kalantzis, 2009; The New London Group, 1996). Design/redesign is one dimension of Janks' critical literacy education theory (2010) that acknowledges the relationship between literacy and power in positioning readers to align themselves with the 
particular views of a text. The theory is underpinned by the four interrelated dimensions of power, access, diversity and design/redesign that afford an examination of the ways texts are constructed to promote certain views, voices and modes, thereby privileging the interests of some people and ideas at the expense of others. The dimensions are interrelated in that the power of a text is related to the diversity of the views shared and the modes through which meaning is made that privilege certain discourses (for example, academic versus vernacular language), potentially denying access for some to that text (Comber, 2013; Janks, et al., 2014). According to Janks' critical literacy theory (2010), transformation can occur through understanding and responding to the design of a text through redesign.

Janks' (2010) design/redesign dimension (Figure 1) engages the learner in critical literacy education through deconstruction and reconstruction of text.

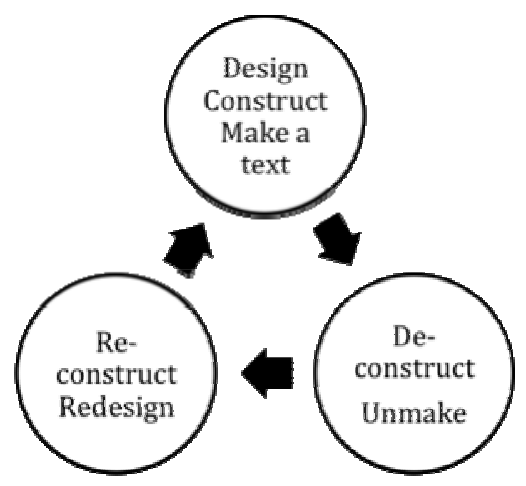

Figure 1. The redesign cycle (Janks, 2010)

In deconstructing or unmaking a text, learners initially consider its power by examining the interests at play. That is, they "name the problem" (Janks, 2010). They identify perspectives shared, voices heard and beneficiaries of this view, while exploring the ways those meanings are represented in its design. In naming the problem, the reader creates the opportunity to imagine other perspectives.

In reconstruction, learners look to ameliorate power with a view to diversifying perspectives and voices by considering viewpoints and experiences not represented within the original text (Cope \& Kalantzis, 2009; Janks, 2010; Vasquez, 2010). They imagine alternative ways for that message (Janks, 2014), they consider their access to linguistic and cultural resources for text creation (Comber, 2011), and they transform this understanding to the creation of new texts (Harste, 2014; Kress, 2010).

Kress and van Leeuwen (2001) observed that the act of redesigning a text is transformative because it is created "with the agentive force of individual interests" (p. 63). Cope and Kalantzis (2009) support this argument because redesign represents new meanings through new authorship within unique sociocultural settings. Similarly, Janks (2014) clarified that learners' alternative perspectives on the "problem" achieve transformation when they aim to "improve the way we live and relate to one another" (p. 8). That is, transformed texts focus on issues of social justice and action (Cope \& Kalantzis, 2009; Janks, 2010; Luke, 2012). The transformative nature of redesign is of interest in this inquiry where students responded to the ideologies they identified in Ruhemann and Tan's The Lost Thing (2010) short film.

\subsection{Making Meaning from The Lost Thing Short Film}

Ruhemann and Tan's (2010) Oscar winning short film The Lost Thing is the literary text that was the focus for critical literacy teaching reported in this paper. It is a 15 minute animated clip combining $3 \mathrm{D}$ computer generated imagery with hand-painted components that were included to convey the "reality" of the scenes (passionpictures.com). Its synopsis promotes ideologies of belonging where, "a boy discovers a bizarre looking creature... Realising it is lost, tries to find out who owns it or where it belongs... and sets out to find a "place' for it" (passionpictures.com).

It is not the intention in this paper to conduct a literary critique of The Lost Thing (Ruhemann \& Tan, 2010) short film. However, it is useful to consider the findings from analysis of The Lost Thing by children's literature theorists because it is these analyses that informed the planning for and programming of the critical literacy lessons conducted with the child participants in this study.

Literary critique examines the overt, passive and underlying ideologies (Hollindale, 1988) within a text in connection with the social and cultural contexts within which it was created. The Lost Thing picturebook (Tan, 2000) and short 
film (Ruhemann \& Tan, 2010) have attracted a range of critiques. Relevant to this inquiry are Hateley's (2013) analysis of the ideologies conveyed about society's social roles and responsibilities in the short film, Rudd's (2010) examination of the connections between the text and Australian culture and the arts, and Dudek's (2005) critique of Tan's The Lost Thing picturebook (2000) that also relate to the short film.

Hateley (2013) observes that the main creature in The Lost Thing "seems intelligent, seems incapable of communication, seems to be alone, seems to be without home, and seems purposeless" (p. 2). The boy assumes the creature is lost and therefore requires his assistance. He also surmises that the creature is without an owner, constructing it further as an object (Dudek, 2005; Rudd, 2010). Hateley (2013, p. 2) explains that the boy character then "sets about finding a permanent and correct place" for the creature, something Rudd (2010) observes is a key feature in notions of belonging; not only must one have a "place or home" but that its validity rests with the acknowledgement of others (p. 134).

The creature is apparently unseen by the workers in the story, despite its considerable size and bright colour. Dudek (2005) argues this implies a loss of "ability, or desire, to see or read the world beyond the television, the newspaper, the signage, the dollar" (p. 59). The character of Pete contrasts the unseeing workers by offering the boy character an alternative way to see the world (Dudek, 2005; Hateley, 2013), prompting the boy to take the creature home to a hostile reception from his parents.

In the final scenes of Utopia, the creature is constructed as having found its place. However, Hateley (2013) observes that, in fact, the Utopian creatures are like the original creature only "insofar as they are unlike each other or anything else the reader has seen in [the boy character] world" (p. 3). This is an interesting contrast from the characters in the human world whose differences are almost indiscernible.

The Lost Thing short film and literary critique offers opportunity for working with students to develop their ability to identify and critique the ideologies they perceive and then imagine new perspectives to be shared in redesigned texts. In the creation of these redesigns, The Lost Thing's screen based computer animated features can be somewhat mirrored by combining sound, movement, image and language using the unique properties of iPad technology.

\section{Research Design}

The following question guided this study:

How do Grade 6 students in one school respond to messages they identify in The Lost Thing through the creation of redesigned texts?

\subsection{Participants}

The participants were 42 Grade 6 primary school students in a regional area of New South Wales, Australia. Critical literacy historically focuses on empowering marginalised groups like cultural minorities to change their lives (Cope \& Kalantzis, 2009; Lee, 2011). However, this research sought participants from middle income, native English speaking backgrounds, that is, those from a dominant group in their local community. Foss and Carpenter (2001) argue that all learners "need and deserve" (p. 403) opportunities to develop critical literacy skills in order to problematise and challenge the relationships of literacy and power in their own lives. Further, without opportunities to challenge uncontested views promoted in the predominantly Western centric texts of schools, learners from dominant cultures are in danger of accepting these very familiar cultural views as a "barometer" (Flanagan, 2013, p. 18) or "the norm against which to judge other perspectives and cultures" (Short \& Thomas, 2011, p. 157). While the participants' school was located in a middle income, culturally homogenous suburb of mainly native English speakers, it is important to acknowledge that there is no presumption of homogeneity among the participating children simply because of their cultural and social backgrounds. While similarities within the group are expected, each child will clearly have had different experiences, responded to diverse expectations, engaged with their unique home practices and developed individual perspectives on the world based on these interactions.

\subsection{Procedures}

The students participated with the teacher and researchers in seven workshops focused on teaching critical literacy framed by Janks' (2010) redesign cycle. The students worked in pairs or alone to create digital literary texts (redesigns) in response to the ideologies they perceived in The Lost Thing (Ruhemann \& Tan, 2010). The workshops are summarised in Table 1, and a complete account can be accessed at Mantei and Kervin (in press). Classroom data collected were: classroom observations (field notes, still and moving images), semistructured interviews with students and student work product. Student work product included design drafts, final redesigns and reflections throughout the process. Researcher field notes were also taken. 
Table 1. Redesign Workshops summary

\section{Workshop 1: Understanding design}

- View The Lost Thing

- Teacher instruction: Through discussion, teacher and children identify messages and perspectives and how these were achieved modally using questions such as, What is something this story is telling you? How do you know?

- $\quad$ Student independent writing and reflection: Identifying messages perceived and dominant modes through which they were conveyed through writing and drawing.

\section{Workshop 2: Reflection - visual analysis}

- Teacher instruction: Investigate and identify the use of colour, vector, shadow and salience at key points in the film using print outs of screen captures and deconstructing an example. Students then completed their own analysis on a different scene.

- Student independent writing and reflection: identify and explain a colour, a symbol and image that supported their understanding of the messages within The Lost Thing

\section{Workshop 3: Deconstruct/unmake the text}

Focus on critical literacy questions: Whose voice is heard? silenced? What is the effect?

- Teacher instruction: Analyse author craft, digital features, literary techniques by capturing and deconstructing the messages conveyed through different modes.

- $\quad$ Student independent writing: Working in pairs or alone, brainstorm alternative views, possibilities for design and build the intention to create

- Student reflection: share intentions for redesign

Workshop 4: Reflection - preparing to redesign

Focus on critical literacy questions: Who else? What else? How else? For whom?

- Teacher instruction: Demonstrate the taking of alternate views, e.g. What if The Lost Thing was not welcome in the colourful world?

- Student independent writing and reflections:

- Connect: identify text-to-self, text and world connections to The Lost Thing

- Challenge: a perspective in The Lost Thing

- Identify important Concepts in The Lost Thing and in the redesign

- Identify Changes or action to be promoted in the redesign

\section{Workshop 5: Reconstruct/redesign}

- $\quad$ Student independent writing workshop:

- Critique affordances of the apps as tools for creating redesigns

- Articulate purpose of the redesign, draft script, storyboard the plot, gather images, plan the performance

- Provide and receive feedback on redesign final draft

- Create the redesign and upload to the repository for sharing

- Student reflection: describe the modal combinations planned for the new design

Workshop 6: Reflection - Step inside

- Student independent writing workshop:

- Personal viewing and critique of own digital texts with the original short film

- Conference with teachers and peers about the modal choices and their cohesion

- Student reflection: share reflections about the redesign process and messages conveyed

Workshop 7: Redesign launch - celebration and feedback

- Launch redesigns in a public forum

- Provide feedback for each other and make recommendations for future texts

- Student reflection: process, product, peer feedback and possibilities for future redesigns 
All students used iPads, a device with which they were familiar from daily classroom use. Specifically, they used PuppetPals and iMovie apps for the creation of texts and a repository for sharing drafts and related resources. While the children were familiar with using the iPads, PuppetPals and iMovie as an app were new, but quickly mastered. Following planning and drafting with print based materials, PuppetPals afforded opportunities for rehearsal, reflection and editing prior to script recording with images and movement. Saved drafts were exported to iMovie, where further sound, transitions and effects could be added, along with opening and closing credits acknowledging the sources used. Once published, the students exported their final product for sharing with peers, teachers, parents and researchers.

In total, 25 redesigns were created and shared, 17 from students working in pairs and eight from individuals (indicated as [I] in Table 2). Table 2 lists titles and synopsis of each redesign as a summary and also as a point of reference for the findings shared in this paper. The redesigns are grouped into three broad categories: In redesigns 1-10, the previously lost creature is active in looking for a home. Redesigns 11-15 retell the original story and/or provide further background to the original text. And in redesigns 16-25, the human is positioned as active in saving the "lost" creature from perceived dangers. 
Table 2. A summary of the redesigns created

\begin{tabular}{|c|c|}
\hline $\begin{array}{l}\text { Redesign } \\
\text { Number }\end{array}$ & Title \\
\hline 1. & Nobody did anything worthwhile \\
\hline 2. & $\begin{array}{l}\text { The story of ArtMan, a resilient } \\
\text { individual }\end{array}$ \\
\hline 3. & $\begin{array}{l}\text { How Scarlet came to join our } \\
\text { family }\end{array}$ \\
\hline 4. & $\begin{array}{l}\text { If only everyone was nice to each } \\
\text { other }\end{array}$ \\
\hline 5. $[\mathrm{I}]$ & ...I also found a part of me \\
\hline 6. & $\begin{array}{l}\text { Pushing buttons, pulling } \\
\text { levers...is there something more? }\end{array}$ \\
\hline 7. & $\begin{array}{l}\text { Better than the real world? I'm } \\
\text { willing to take that chance }\end{array}$ \\
\hline 8. & Shaun becomes an alien \\
\hline 9. & $\begin{array}{l}\text {...'m kicking a ball with } \\
\text { Ronaldo! }\end{array}$ \\
\hline
\end{tabular}

10. Pete gives peace to creatures

11. [I] I used to belong...

12. [I] I wonder where that lost thing is?

13. [I] How could a car go so wrong?

14. Bruce the Lifeguard

15. [I] He wasn't so different after all

16. Is it really a monster?

17. [I] Friendship sustains during the famine

18. You're a danger to our civilised society

19. Shaun, protector of Lost Things

20. George, liberator of Lost Things

21. [I] A safe haven

22. Putting them to work - The many uses of Lost Things

23. How I got here

24. [I] If only they could see what we do 25. Breaking the code

\section{Synopsis}

The Lost Thing is not lost. It is looking for a new and more meaningful life.

Rejected by artists and customers at a local gallery, ArtMan searches for true recognition of his talent.

The Lost Thing finds a home in the "real" world despite appearing quite different from her peers.

Stranded, The Lost Thing wanders until it finds a place to belong and a friend as well.

Set in New York city, a boy defies the advice of the adults and befriends a Lost Thing.

Small, colourful creatures - "Lost Things" - change the mundane lives of a pair of workers.

An outcast, fleeing from The Unknowns finds refuge in a new land, The Rainbow Area.

Shaun's experiences in the alien world open his eyes to new possibilities for friendship and belonging.

A boy who dreams of playing professional soccer is rejected from his non-soccer playing community. Will he triumph in the end?

The Lost Thing chooses to live with Pete (a human) and his collection of other Lost Things.

Bob is made redundant from his job and struggles to find new direction.

The Lost Thing is a mutant, the product of a lab accident. This scientist tells his version of events...

Trying to make a car, a mechanic has a catastrophic accident and tries to make amends.

While on beach patrol, Bruce finds a lost little boy and works hard to reunite him with his parents.

When a girl finds a lost thing in a park, the trouble begins. Who will open their heart and home?

A boy is late for school and stalked by what seems to be a scary creature. But is it?

Dangerous and unfriendly or just misunderstood? This is the story of an unlikely friendship between a boy and a creature.

The Lost Thing, a valuable commodity on the black market, is kidnapped, escapes and is then hunted by The Shouty Men of Gloomyville St.

Shaun was one of the crowd, but a chance meeting with The Lost Thing changed all of that.

When kidnappers invade Utopia, George sets out to find and return its once happy creatures.

When his pet Lost Thing dies from pollution and decline, his owner creates a refuge for other vulnerable creatures in the city.

Shaun's Lost Thing cleans his house, brings him breakfast in bed, and even does his homework! Can other people find uses for Lost Things too?

Some scientists take The Lost Thing into their home and later, finding where it belongs, return it.

Three girls make friends with creatures that adults can't see.

A young boy breaks the robot code controlling people's lives, returning them to happier days. 


\subsection{Data Analysis}

Informing data analysis were: The Lost Thing synopsis (passionpictures.com), literary critiques from Dudek (2005), Hateley (2013) and Rudd (2010), student work samples and reflections, semi-structured interviews, fieldnotes and redesigns.

Data were analysed in two ways. The first aimed to account for the complexity of the entire data set as an example of critical literacy learning, and the second to afford an examination of just the redesigns as multimodal texts in an effort to understand their design (Janks, 2010). The first used principles of Janks' critical literacy theory (2010): naming the problem; imagining new perspectives; and promoting improved understandings of and relationships with others. These principles acted as a lens through which the ideologies within the students' texts could be analysed. Specifically, student work samples, reflections on the learning and the final product were analysed for evidence of the principles. This analysis was completed for each participant initially by the first named researcher and then by the second in an attempt to achieve reliability in the analysis.

Then, a multimodal lens supported an examination of the materiality of the modes and the intersemiotic relationships within each redesign (Jewitt, 2013; Norris, 2004). That is, each author's design was examined through their selection and use of the modes (Kress \& van Leeuwen, 2001) and the ways they were combined to align with, complement or contradict the message. Rather than attempting to quantify modal usage, the analysis examined their interactivity in creating the message (Norris, 2004). As such, the redesigns were viewed in their entirety, then broken into scenes and screen captures taken for each scene and the script included underneath. New "scenes" were determined as follows: visually, a change in background design; linguistically, a pause or change of focus; and aurally, change of music or sound effects. For example, in Redesign 2 (see Table 2), "Art Man", lauded as a talented artist is traumatised by harsh critiques, flees the gallery in search of a more appreciative audience, and finally settles into a happier existence where he feels like "a whole new artist". Three scenes from this story are shown in Figure 2.

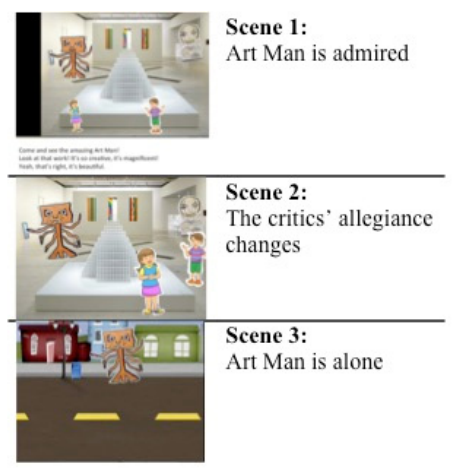

Figure 2. Scenes from Redesign 2 for analysis

Each scene presents a new source for analysis of the ways the modes work together to convey Art Man's rejection. Within each scene, spatial and gestural elements such as proximity, position and body language were analysed in connection with the authors' linguistic, visual and audio choices. In the Art Man example, scenes 2 and 3 have no narration because the story is told through dramatic audio, slow movement, and the isolated positioning of the characters. In this more complex analysis, the first named researcher again conducted the initial analysis and the second researcher analysed every third redesign in an effort to ensure the findings were aligned.

\section{Findings Reported through the Principles of Redesign}

Findings from both levels of analysis are reported using Janks' (2010) principles of critical literacy theory: naming the problem; imagining new perspectives; and promoting improved understandings of and relationships with others. Within these, examples of modal assemblages and the students' reflections demonstrate how meaning was built.

\subsection{Naming the Problem}

In their deconstruction and critique of The Lost Thing, students were encouraged to identify existing ideologies they felt warranted further examination. Students' reflections and work samples demonstrated a perception that the story conveyed ideologies about the desire to belong, and a person's responsibility for others. One student explained, "The message I notice was everyone has a place where they belong". Another student expressed the perception of being responsible for greater inclusion, "...to look out for people and help them find where they belong". A pair of students 
reported a sense of being called to "pay attention to others", accompanying this observation with one colour and an image from the story that were annotated to explain their thinking about the "problem" in the story (Figure 3).

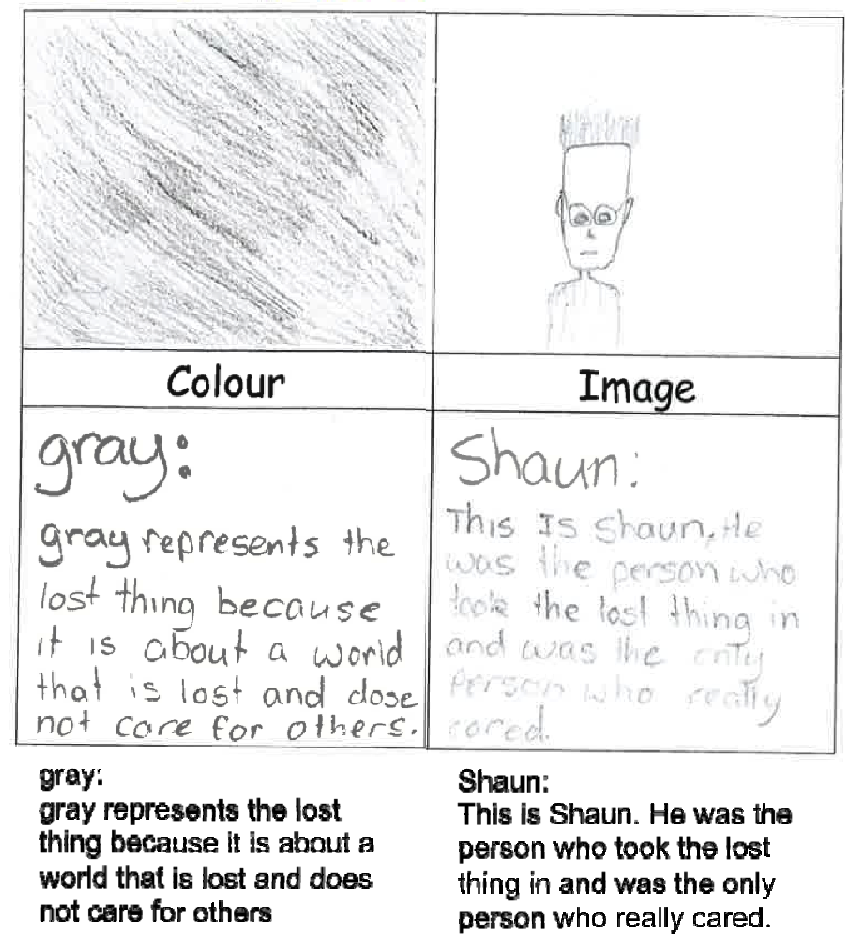

Figure 3. Two students identify a sense of loss in the short film

Evident in this image is the students' emerging understanding of the ways the modes combined to create a sense of being lost. For example, they describe the use of the colour gray from the short film as representing loss and lack of care, and the boy character (Shaun) is depicted as serious and unsmiling in this uncaring environment. A stark contrast is seen in these students" redesign (Redesign 8) where the "alien" world is madly colourful and its residents welcoming. An example of this redesign is shared in Figure 4.

In critique, the students were invited to challenge these assumptions through conversations with a partner and then written reflections. One student observed a tension present in the messages he had perceived, stating, "just because something is different doesn't mean it is lost”. Another argued, “...people don't need to be categorised”. One student explained to her partner during observations, "some people like to be alone and should be left alone". The invitation and opportunity to identify and problematise ideologies appears to have created opportunities for students to explore alternative perspectives on belonging.

\subsection{Imagining New Perspectives}

In the second stage of the redesign cycle, the students explored voices heard and silenced within the short film. In imagining new perspectives, they considered who else could have a view about belonging, what else could be told, how else this perspective could be conveyed, and for whom they could share this new perspective. Again drawing on reflections and work samples from relevant workshops, evidence of new perspectives emerged. For example, one pair of students wondered, "What if the Lost Thing wasn't lost?" and subsequently redesigned their "lost" creature with a new colour. They made it bright green, a colour they described as "calmer" that would "look for its own home". Another student asked how people could fail to "notice the massive big lost thing", a question that would feature in their final redesign, Redesign 1 (see Figure 5).

In other reflections, students challenged implied ideologies related to place and community. For example, one pair challenged the utopic nature of Utopia as "the happiest place around" and instead positioned it as a place where inhabitants "never did anything worthwhile". Another wondered if there was "any evidence that Shaun didn't actually take the Lost Thing out of its life", challenging the idea that the human and Lost Thing's world are in fact different 
places. Imagining new perspectives provided the students with choices about ideologies for inclusion in their own texts (Serafini, 2012) that would promote improved understandings of and relationships with others.

\subsection{Promoting Improved Understandings of and Relationships with Others}

The students' ability to critique became clear in their multimodal digital literary texts. Twenty of the 25 redesigns promoted social action. That is, the texts had worked to reposition the prevailing discourse (Luke, 2012) of belonging that the students had detected in The Lost Thing in favour of a broadened, more active and inclusive version. This was evident in the ways so-called "lost things" are viewed and treated in the redesigns. The "lost" characters, human and alien, became agentive in finding their place, and the inhabitants of these "places" were more flexible and accepting of diversity and difference. While some stories saw the lost character return to its own world, others had it choosing to join others less like itself. In all cases, the lost creature was proactive in selecting its final place. For example, in Redesign 7 (see Table 2), the authors explain that the lost character is "willing to take the chance" for a better life by following his unicorn friend to "The Rainbow Area" to escape his hunters. Similarly, the creature in Redesign 8 remains in the alien world into which he had stumbled. A multimodal analysis of the final scene of Redesign 8 demonstrates the characters' sense of belonging not only in the script, but visually and aurally in the finale (Figure 4).

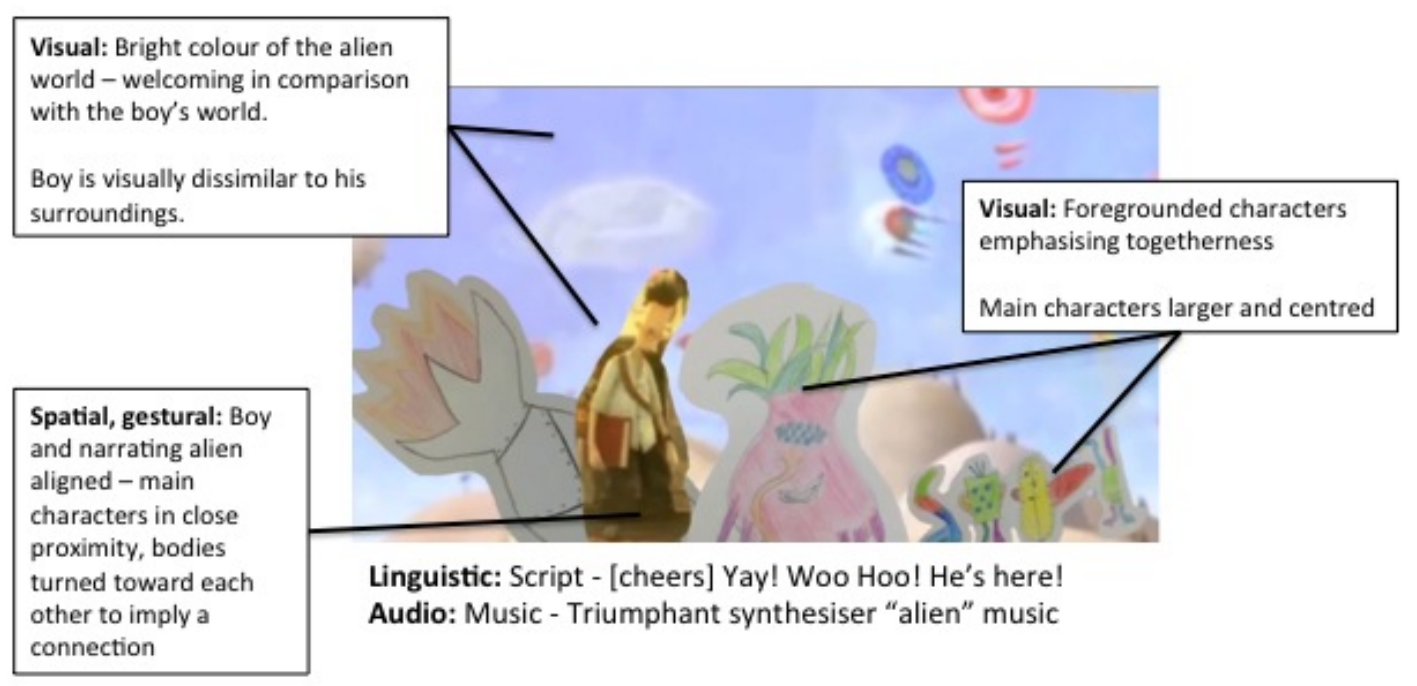

Figure 4. Redesign 8 a sense of belonging is established

At interview, the authors revealed their intention to promoting difference and diversity,

The human wants to be somewhere where he fits in and he doesn't have to be like everyone else, he can just be himself... so the aliens take him back to the colourful planet where he can be himself....

A sense of estrangement was also observed in some redesigns as authors shared their creatures' journeys toward belonging. For example, in the opening scenes of Redesign 1, the narrator moves through the city unnoticed, despite its considerable size and distinctive red colour. The script, "The people were strange. None of them seemed to notice me when I passed by", is juxtaposed visually, drawing the viewer's attention to the irony that it is actually the people who are unseen (and unseeing), obscured by the narrator's bulk (see Figure 5). 


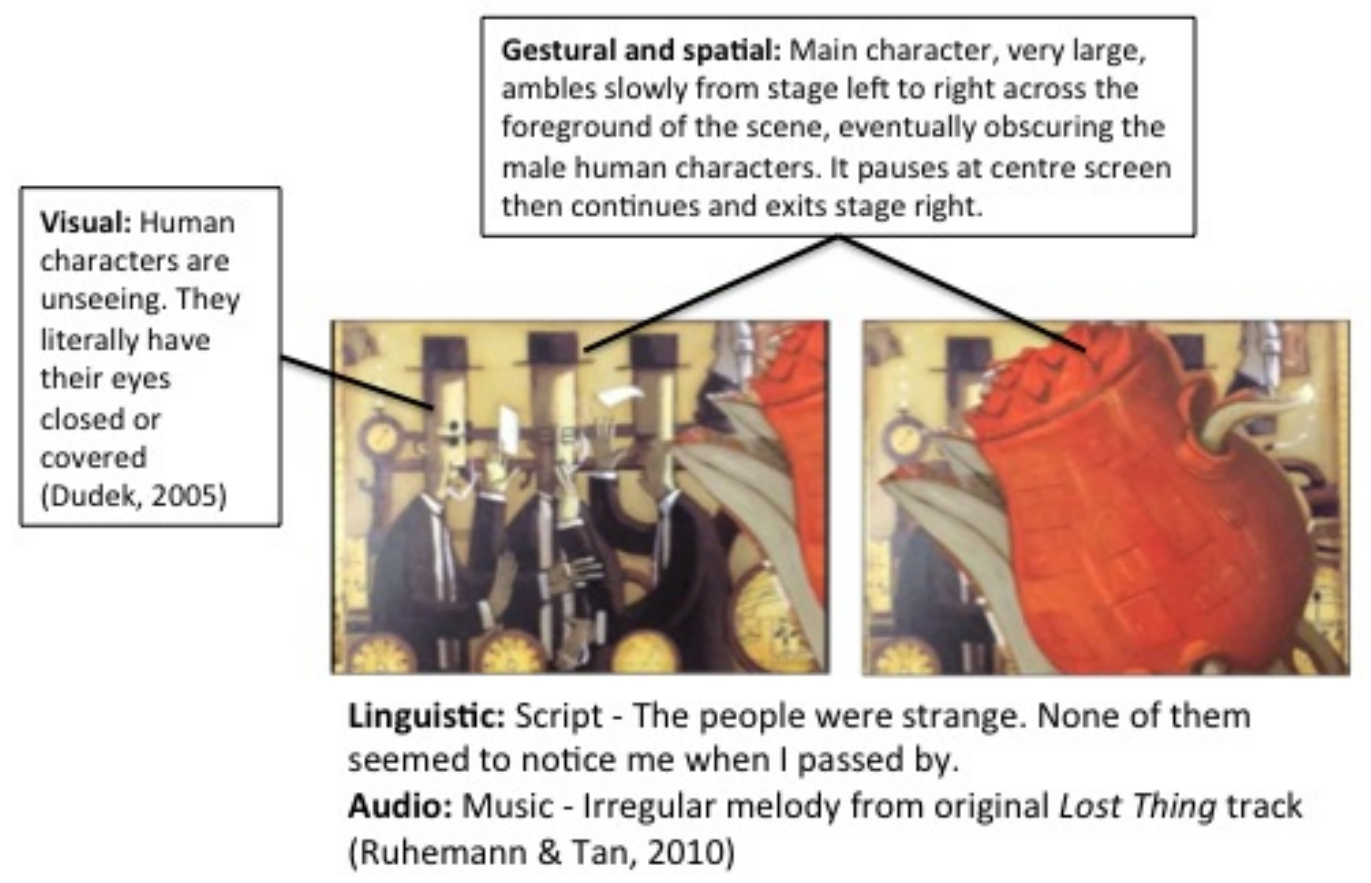

Figure 5. Redesign 1, the authors convey the irony of being huge yet unseen

At interview, the authors explained,

Our story's about how the last thing isn't actually lost...it actually went for an adventure but Shaun thought it was lost and so he took it back home...our main message is just because something is different doesn't mean that it is lost.

This story concludes with a sense of business unfinished and perhaps new adventures as the narrator states, "...maybe I might go back some day". The disconnect from Utopia is reflected spatially and visually with the narrator positioned high on the periphery of the screen, very small, perhaps an outsider (Figure 6).

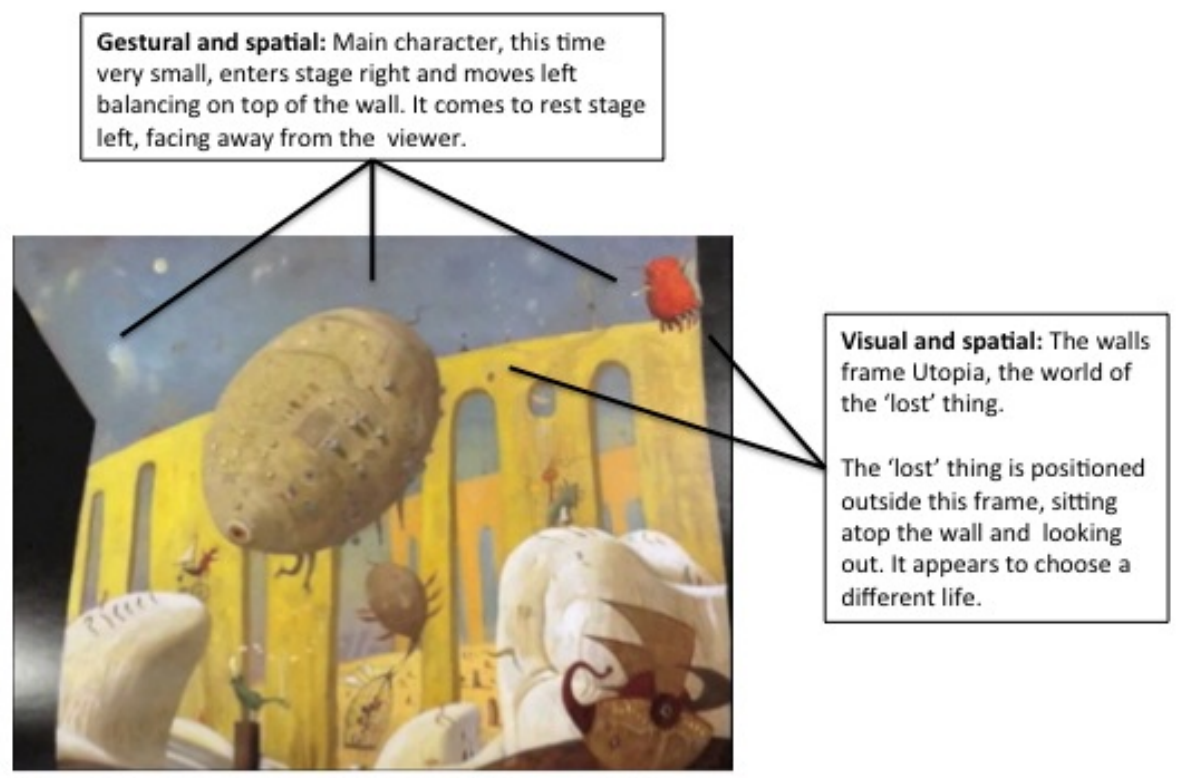

Linguistic: Script - He didn't think I belonged in his world. But maybe I might go back one day.

Audio: Music - Crescendo of melody from original Lost Thing track (Ruhemann \& Tan, 2010)

Figure 6. Redesign 1, a sense of estrangement is established 
The redesigns shared thus far provide examples of what "might be possible" (Comber et al., 2001, p. 423) in terms of challenging existing ideologies of belonging the students perceived in The Lost Thing (Ruhemann \& Tan, 2010). Janks' (2010) redesign cycle appears to have supported students' critical literacy skill development through the deconstruction of the design of texts and a subsequent opportunity for reconstruction through redesign. In these redesigns is a call to social action for better treatment of those who are considered different in society and for those who are considered "lost" to be proactive in locating their place.

However, five redesigns (11-15 in Table 2) demonstrated a different version of redesign. Like the others, these authors engaged in critique by identifying ideologies and transforming this view to create a new text. But they were different in that they offered an instantiation of the themes identified in the original text, either by providing the backstory to The Lost Thing (Ruhemann \& Tan, 2010), or by retelling the story in a new setting. To elaborate on the backstory, the authors of Redesigns 11 and 12 told the story about how Ruhemann and Tan's (2010) creature came to be lost. Redesign 11 sees the Lost Thing, once important and relevant in the workplace, made redundant and subsequently left without purpose, justifying its aimless wandering on the beach. Similarly, Redesign 12 finishes with the creature on the beach, as a scientist relates the story of experiments gone wrong and a terrible mutation of what was to be a car. With the mutant creature seemingly stranded alone, the scientist narrator appears to regret his actions as he muses about its safety and future (Figure 7),

I wonder where that thing would be, where the thing is...how will he find his way home?...Oh how I liked that lost thing. I hope he has friends sometime soon.

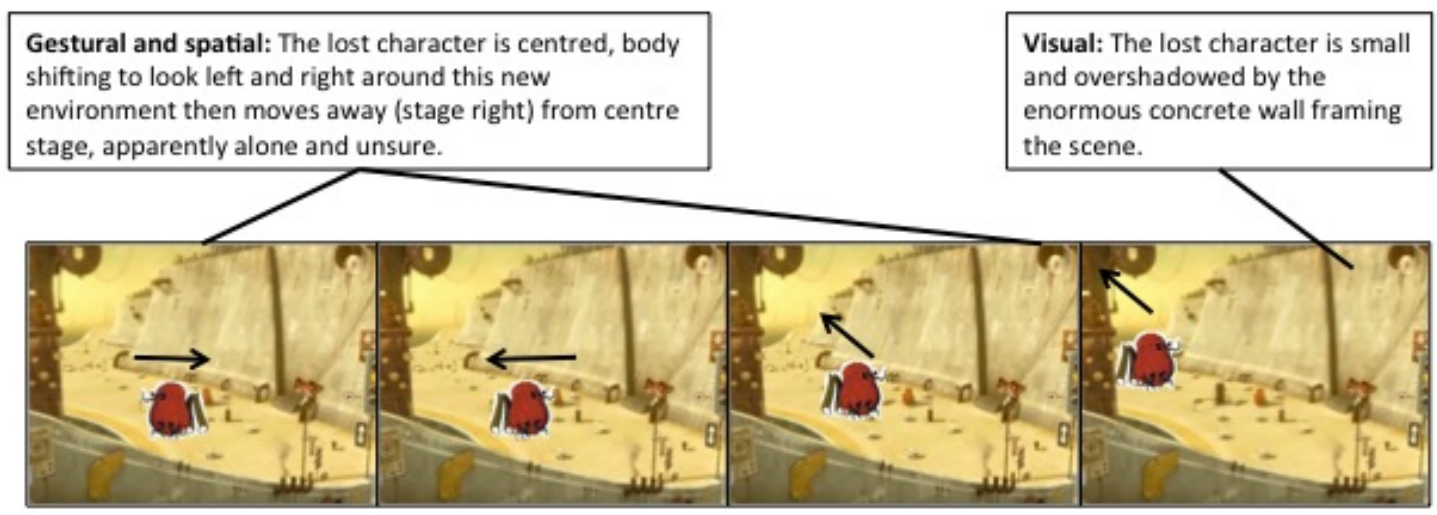

Linguistic: Script ...how will he find his way home? Sometimes I juuuust wonder where he could be. I just hope he finds friends some time soon.

Audio: Music - Quiet, wavering melody from original Lost Thing track (Ruhemann \& Tan, 2010)

Figure 7. Redesign 12, the author uses size, proximity and movement to convey loneliness

The narrator's wish for a friend for the mutant creature is echoed in reflections shared during workshops focused on naming the problem. The author stated, "I would probably change the idea of the man finding the lost thing taking it to utopia. The man should be happy and take it home". However, by only providing the backstory to the original, the student was not able to convey this new perspective to the viewer.

While this group of students' redesigns have transformed the ideologies from one text to the creation of another, a focus on change through social action is unclear. These students had opportunity to engage in critique, but it appears there has been limited problematisation of the original themes and therefore no challenge has been made. Existing messages of belonging are promoted in their instantiations (Janks, 2010). However, in terms of transformation, these students have explored their own understandings of belonging and their own sense of self within their communities and expressed these in a digital multimodal literary text.

\section{Discussion}

This inquiry examined Janks' (2010) redesign cycle in the development of Grade 6 students' critical literacy skills as they created redesigns that challenged existing discourses about the messages they perceived in The Lost Thing short film. Data were analysed through the dimension of redesign from Janks' (2010) critical literacy education theory: naming the problem; imagining other ways; and promoting relationships with and understanding about others. Multimodal analysis supported an understanding of the ways the authors constructed their messages, and student work samples, reflections and semi-structured interview transcripts grounded the findings in the children's learning. In 
response to the research question, the following discussion focuses on literary text as a stimulus; Janks' (2010) redesign framework for developing critical literacy skills; and student responses to the process. It finishes by considering some implications for developing critical literacy skills related to the findings of this paper.

The Lost Thing is a sophisticated and complex text (Gibson \& Ewing, 2009) offering its audience opportunities to interpret and reflect on a range of ideologies. The text allowed students to examine messages conveyed about their place as members of a community, responsibilities associated with that place (Arizpe et al., 2013; Kalantzis \& Cope, 2012), and their own beliefs about those views (Janks, 2014; Vasquez, 2010). In redesign, the students were empowered to promote new perspectives through the creation and sharing of their own meaningful and complex literary texts in response to their present and future communities.

Janks' (2010) redesign framework acted as a supportive frame for engagement in initial deconstruction and critique as consumers of literary text. The act of "unmaking" the text (Janks, 2010) supported the students' analysis of the multimodal ensemble (Jewitt, 2013) with a view to the later creation of their own multimodal digital text. And the opportunity for redesign as they drew upon their own abilities and shared new perspectives allowed students to position themselves as text creators.

The students' engagement with the selected text and the redesign process required them to draw on existing knowledge about and experiences of the nature of literary texts, their physical construction across a range of modes and the use of technology for the creation of new texts. The process invited the students to draw on their knowledge of text and the modes to share literal, figurative, critical and creative interpretations (Holliday, 2008). Through their activation of different modes, they demonstrated complexities in theme that may have been difficult to represent in written text alone.

The task also required them to activate their knowledge of the world more broadly. For example, the students were drawn to consider their understanding of the ideological construct of "belonging". As early adolescent members of a predominantly white, English speaking middle class community, they brought a range of experiences, knowledge and understanding to their interactions with text. However, the knowledge of any adolescent about social justice issues such as marginalisation and silenced views will be, as observed by Short and Thomas (2011), limited by their age and life experience. In most of the students' redesigns, an obvious challenge was made in deconstruction and problematisation of an ideology perceived in the original text. Further, the productive power of redesign was evident in the presentation of new perspectives of belonging designed to promote improved understanding of and relationships with others. These redesigns are transformative in that they promote justice through social action and demonstrate the authors' understanding of their roles in its achievement.

However, evidence of critical literacy in some redesigns was less clear. Problematisation of the original themes was limited, thus, maintaining the status quo, which may be unsurprising given the student authors' age and experiences (Short \& Thomas, 2009). These authors aligned themselves with the ideologies of the original text, sharing what Janks (2010) terms a personal rather than social perspective. As such, it appears these redesigns cannot be considered transformative because they lack a focus on social action. However, this conclusion is confounded by Kress and van Leeuwen (2001) and Jewitt's (2013) observation that all redesigns are transformative because of the unique opportunities they offer for explorations of one's place in the world, to share a developing sense of self and to position the creator as agentive in defining the future (Comber, 2013; Luke, 2012).

Janks' (2010; 2014) observations about big P Politics and little p politics offer some clarity. Janks (2010) described little $\mathrm{p}$ politics as "the micro-politics of everyday life...the politics of identity and place...of small triumphs and defeats" where "the personal is political" (p188, original emphasis). In these redesigns, viewers were shown something of the authors' personal views, values, experiences and imaginings, potentially improving relationships and deepening understandings between groups, despite the absence of a call to action. Kress (2010) argued that transformative action "remakes...inner resources; and in that, changes [ones] potential for future action in and on the world" (p. 14). Students in this study who created a text considered personal rather than social have perhaps demonstrated an "awakening" of critical literacy skills, where they have controlled just the principles of deconstruction and critique without achieving a call to social action.

\section{Implications and Conclusion}

A broadened definition of 'text' is essential for teaching and learning about critical literacy using digital multimodal literary texts. When educators expand their understanding of what constitutes text (both for the viewer and the creator), new learning opportunities emerge. The short film literary text was a powerful stimulus. It allowed teacher-led deconstruction and critique of a complex multimodal text not only in terms of its messages, but also its design. This in 
turn supported students to reflect on their understanding of design and to explore new ways of representing and communicating through their own unique modal arrangements.

Each student's redesign represents a unique transaction with the short film. They represent students' personal interpretations and exploration of new possibilities for improved relationships with others. The redesigns also represent the range of students' skills with critical literacy, prompting reflection about the pedagogies for critical literacy skill development. To position learners along a continuum of critical literacy skills would allow educators to provide explicit teaching about problematising messages in texts. Learning experiences could then incorporate appropriate deconstruction and construction of text that addresses differing abilities with critical literacy for multimodal digital text creation. The findings shared in this paper suggest that further research into a continuum of critical literacy development related to understanding the content and modal structure of texts could offer insights into critical literacy pedagogies that would benefit all learners.

\section{Acknowledgement}

Figures 4-7 include images with permission from The Lost Thing by Shaun Tan, Lothian Children's Books, an imprint of Hachette Australia, 2000.

\section{References}

Arizpe, E., Farrell, M., \& McAdam, J. (2013). Opening the classroom door to children's literature: A review of the research. In K. Hall, T. Cremin, B. Comber \& L. C. Moll (Eds.), International handbook of research on children's literacy, learning and culture (pp. 241-257): John Wiley \& Sons, Ltd. http://dx.doi.org/10.1002/9781118323342.ch18

Comber, B. (2011). Changing literacies, changing populations, changing places - English teachers' work in an age of rampant standardisation. English Teaching: Practice and Critique, 10(4), 5-22.

Comber, B. (2013). Schools as meeting places: Critical and inclusive literacies in changing local environments. Language Arts, 90(5), 361-371.

Comber, B., Thomson, P., \& Wells, M. (2001). Critical literacy finds a "place": Writing and social action in a low-income Australian grade 2/3 classroom. The Elementary School Journal, 101(4), 451-464. http://dx.doi.org/10.1086/499681

Cope, B. \& Kalantzis, M. (2009). "Multiliteracies": New literacies, new learning. Pedagogies: An International Journal, 4(3), 164-195. http://dx.doi.org/10.1080/15544800903076044

Dallacqua, A. K., Kersten, S., \& Rhoades, M. (2015). Using Shaun Tan's work to foster multiliteracies in $21^{\text {st }}$-century classrooms. The Reading Teacher, 69(2), 207-217. http://dx.doi.org/10.1002/trtr.1395

Dudek, D. (2005). Desiring perception: Finding utopian impulses in Shaun Tan's The Lost Thing. Papers: Explorations into children's literature, 2, 58-66.

Flanagan, V. (2013). A similarity or different: The problem of Race in Australian picture books. Bookbird, 51(2), 13-22. http://dx.doi.org/10.1353/bkb.2013.0032

Foss, A., \& Carpenter, M. (2002). Peeling the onion: Teaching critical literacy with students of privilege. Language Arts, 79(5), 393-403.

Genishi, C., \& Dyson, A. H. (2009). Children, Language and Literacy: Diverse learners in diverse times. NY: Teachers College Press.

Gibson, R. \& Ewing, R. (2011). Transforming the curriculum through the arts. Melbourne, VIC: Palgrave MacMillan.

Harste, J. (2014). The art of learning to be critically literate. Langage Arts, 92(2), 90-102

Hateley, E. (2013). The art of interpretation: Tracing logics of evaluation in Shaun Tan's The Lost Thing (2000) and Andrew Ruhemann and Shaun Tan's The Lost Thing (2010). In International Research Society for Children's Literature Congress 2013, 10-14 August 2013, Maastricht, the Netherlands. (Unpublished)

Haynes, J., \& Murris, K. (2012). Picturebooks, pedagogy and philosophy. London: Routledge.

Holliday, M. (2008). Strategies for reading success. Newtown, Australia: Primary English Teaching Association of Australia.

Hollindale, P. (1988). Ideology and the Children's Book. Oxford: The Thimble Press.

Janks, H. (2010). Literacy and power. London: Routledge. 
Janks, H. (2014). Critical literacy's ongoing importance for education. Journal of Adolescent and Adult Literacy, 57(5), 349-356. http://dx.doi.org/10.1002/jaal.260

Janks, H. \& Comber, B. (2006). Critical Literacy Across Continents, in Pahl, K. \& J. Rowsell (eds) Travel Notes from the New Literacy Studies: Instances of Practice, Clevedon, UK: Multilingual Matters, pp. 95-117.

Janks, H., Dixon, K., Ferreira, A., Granville, S., \& Newfield, D. (2014). Doing critical literacy: Texts and activities for students and teachers. New York: Routledge.

Jewitt, C. (2013). Multimodal methods for researching digital technologies. In S. Price, C. Jewitt \& B. Brown (Eds.), SAGE Handbook of digital technology research London: SAGE Publications. http://dx.doi.org/10.4135/9781446282229.n18

Kalantzis, M. \& Cope, B. (2012). Literacies. NY: Cambridge University Press. http://dx.doi.org/10.1017/CBO9781139196581

Kress, G. (2010). Multimodality: A social semiotic approach to contemporary communication. Oxon, UK: Routledge.

Kress. G. \& van Leeuwen, T. (2001). Multimodal discourse: The modes and media of contemporary communication. London: Arnold.

Lee, C.J. (2011). Myths about critical literacy: What teachers need to unlearn. Journal of Language and Literacy Education [Online], 7(1), 95-102.

Leland, C., \& Harste, J. (2002). Critical literacy. In J. Kristo \& A. McClure (Eds.), Adventuring with books (13th ed., pp. 465-487). Urbana, IL: NCTE.

Luke, A. (2000). Critical literacy in Australia: A matter of context and standpoint. Journal of Adolescent \& Adult Literacy, 43(5), 448-461.

Luke, A. (2012). Critical Literacy: Foundational Notes. Theory into Practice, 51(1), 4-11. http://dx.doi.org/10.1080/00405841.2012.636324

Luke, A., \& Freebody, P. (1999). Further notes on the Four Resources Model. Reading Online. Retrieved from http://www.readingonline.org/research/lukefreebody.html\#freebody

Mantei, J. \& Kervin, L. (2014). Interpreting the images in a picture book: Students make connections to themselves, their lives and experiences. English Teaching: Practice and Critique, 13(2), 76-92.

Mantei, J. \& Kervin, L. (in press). Using short films in the classroom as a stimulus for digital text creation. The Reading Teacher.

Norris, S. (2004). Multimodal discourse analysis: A conceptual framework. In P. Levine, \& R. Scollon. (Eds.), Discourse and technology: Multimodal discourse analysis (pp. 101-115): Washington DC: Georgetown University Press.

Rosenblatt, L.M. (1982). The literary transaction: Evocation and Response. Theory into Practice, 21(4), 268-277. http://dx.doi.org/10.1080/00405848209543018

Rudd, D. (2010). A sense of (be)longing in Shaun Tan's The lost thing. International Research in Children's Literature, 3(2), 134-147. http://dx.doi.org/10.3366/ircl.2010.0103

Ruhemann, A., \& Tan, S. (2010). The Lost Thing. Passion Pictures.

Serafini, F. (2012). Expanding the four resources model: Reading visual and multimodal texts. Pedagogies: An International Journal, 7(2), 150-164. http://dx.doi.org/10.1080/1554480X.2012.656347

Short, K. G. (2009). Critically reading the word and the world: Building intercultural understanding through literature. Bookbird, 2, 1-9. http://dx.doi.org/10.1353/bkb.0.0160

Short, K.G. \& Thomas, L. (2011). Developing intercultural understandings through global children's literature. In R.J. Meyer and K.F. Whitmore (Eds). Reclaiming reading: Teachers, students and researchers regaining spaces for thinking and action. (pp. 149-166). NY: Routledge.

Tan, S. (2000). The Lost Thing. South Melbourne Vic: Lothian.

The New London Group. (1996). A pedagogy of multiliteracies: Designing social futures. Harvard Educational Review, 66(1), 60-92. http://dx.doi.org/10.17763/haer.66.1.17370n67v22j160u

Vasquez, V. (2010). Getting beyond "I like the book". Creating space for critical literacy in K-6. 